\title{
A inscrição de António Vieira em Histórias de Portugal (séculos XIX e XX): memória e legitimidade
}

Ernesto Castro Leal ${ }^{*}$

${ }^{1}$ Universidade de Lisboa, Lisboa/LX - Portugal

\section{RESUMO}

Neste artigo analisa-se, pela primeira vez na historiografia, algumas lógicas das versões intelectuais sobre o significado da função histórica desempenhada pelo padre António Vieira. Essas versóes radicam-se em diversas visóes do mundo dos vários autores portugueses escolhidos que escreveram Histórias de Portugal de audiência pública assinalável nos séculos XIX-XX. Na amostra selecionada, os discursos históricos produzidos revelam a vontade de, através de historiografias com ampla intenção cívica, contribuir, sob diversas matrizes ideológico-políticas, para a construção de representaçôes identitárias portuguesas dentro das conjunturas de construção e de transformação dos nacionalismos.

Palavras-chave: Portugal; António Vieira; historiografia; política; nacionalismo.

\section{The inscription of António Vieira in Histories of Portugal $\left(19^{\text {th }}\right.$ and $20^{\text {th }}$ centuries): memory and legitimacy}

\section{ABSTRACT}

This article examines, for the first time in the historiography, the logic behind various intellectual approaches to the significance of the historical role played by padre António Vieira. These approaches are rooted in the different worldviews of the Portuguese writers who wrote Histories of Portugal for a broad public audience in the nineteenth and twentieth centuries. In the sample chosen, the historical discourses produced reveal a wish to contribute, by way of historiography as a broad civic intervention of varying political and ideological stripes, to the construction of Portuguese identity representations within a framework of nationalism construction and transformation.

Keywords: Portugal; António Vieira; historiography; politics; nationalism.

DOI: http://dx.doi.org/10.1590/2237-101X02204602

Artigo recebido em 9 de dezembro de 2019 e aceito para publicação em 8 de junho de 2020 .

* Professor da Universidade de Lisboa / Faculdade de Letras / Departamento de História, Lisboa/LX - Portugal. E-mail: castroleal@letras.ulisboa.pt. ORCID: https://orcid.org/0000-0002-6128-1614. 


\section{La inscripción de Antonio Vieira en las Historias de Portugal (siglos XIX y XX): memoria y legitimidad}

\section{RESUMEN}

En este artículo se analiza, por primera vez, en la historiografía, algunas lógicas de las versiones intelectuales sobre el significado de la función histórica desempeñada por el padre Antonio Vieira. Esas versiones se arraigan en diversas visiones del mundo de los varios autores portugueses escogidos que escribieron las Historias de Portugal de la audiencia pública notable en los siglos XIX y XX. En la muestra seleccionada, los discursos históricos producidos revelan la intención de, a través de historiografías con amplia intención cívica, contribuir, sobre diversas matrices ideológicas y políticas para la construcción de representaciones identitarias portuguesas dentro de las coyunturas de construcción y transformación de los nacionalismos.

Palabras clave: Portugal; Antonio Vieira; historiografía; política; nacionalismo.

\section{Introdução}

A produção da análise crítica do passado por parte do historiador é por vezes desvirtuada pela sua envolvência ideológico-política na cidadania, incorrendo nos riscos da apologética ou da exautoração, isto é, em "literaturas de justificação" ou em "histórias aplicadas". O resultado seria a produção de uma "história-tribunal" ou de uma "história-mestra da vida", de que falou o historiador Lucien Febvre, distantes, por conseguinte, da história crítica e situada enquanto "estudo cientificamente conduzido" (FEBVRE, 1977, p. 37-58), em virtude do "uso e abuso da História" - título de uma coletânea de ensaios de Moses Finley (1989) - como lugar legitimador de discursos. O campo historiográfico é estabelecido a partir de perguntas e da escolha de documentos, portanto de uma relação de valores entre o sujeito e o objeto, daí o fundo do problema para o historiador não ser o de anular as ideologias que o condicionam mas sim o de optar pela natureza do sentido e significado a imprimir à compreensão histórica.

A perspectiva historiográfica contemporânea molda-se na relatividade objetivante evitando o relativismo subjetivista, dispondo para tal de regras de procedimento metodológico e de produção do discurso (FOUCAULT, 1977; VEYNE, 1983; MATTOSO, 1988; HESPANHA, 2003; CATROGA, 2011; GODINHO, 2013). Entre a ação e o pensamento é difícil estabelecer uma separação e, por conseguinte, toda a realidade construída é relativa ao processo de seleção e de escolha dentro do mundo de motivaçóes e do método 
do autor, por mais que ele esteja convencido da hipótese da objetividade do discurso, configurando desse modo uma inevitável relaçáo de intersubjetividades (FOUCAULT, 1992). Mas pode-se questionar o processo e as motivações da seleção dos fatos históricos convocados para o processo de construção do conhecimento analítico (GODINHO, 2009, p. 21-47). O historiador Vitorino Magalhães Godinho colocou a urgência de seguir três caminhos: "desideologização do pensamento científico", "colocar a problemática no centro da investigação científica" e "recurso a todo o instrumental das diferentes ciências" (GODINHO, 2013, p. 185).

O ser humano, ao vaguear pelo "tempo-memória" com finalidade interveniente, propicia sempre um ato comunicativo que apela a uma cumplicidade publicamente partilhada através da adesão ou do consentimento (ARIĖS, 1986, p. 69-86). A história ao ser interpretada e comunicada como historiografia permite a generalização de atitudes e de valores que, ao ativar um sistema de relaçôes interindividuais, tende a criar uma área de opinião pública e um longo "efeito-écran" que pode distorcer a perceção crítica dos processos históricos. Assinale-se os casos paradigmáticos na cultura e na política portuguesa de Antero de Quental, com a conferência Causas da decadência dos povos peninsulares nos últimos três séculos (1871), que adquiriu um estatuto mítico como "literatura de justificação" (CATROGA, 2001; LOURENÇO, 2008), ou de Oliveira Martins, com o livro Portugal contemporâneo (1881), que formalizou uma "história aplicada" na análise da vida portuguesa entre 1826 e 1875 (MACEDO, 1981).

Se se verificar a generalização de um contágio socialmente alargado, a memória individual amplia-se em memória de grupo e até em memória da nação, recorrendo-se não raras vezes a dimensôes mitificadas dos heroísmos militares (a cruzada da "reconquista cristâ" no processo de construção de Portugal) e das sagraçôes religiosas (o mito do "milagre de Ourique", selando o providencialismo cristáo de d. Afonso Henriques, primeiro rei de Portugal), sendo, nessas circunstâncias legitimadoras, significativas tanto as evidências mitificadas ou históricas como os silêncios produzidos.

A amostra selecionada corporiza alguns "lugares de memória funcionais" (NORA, 1978) para a análise crítica da recepção do padre jesuíta António Vieira (Lisboa, 1608 - São Salvador da Bahia, 1697) (VALENTE, 1980; PÉCORA, 1984; CALAFATE, 2001; CASTRO, 2008) em Histórias de Portugal, escritas somente por autores portugueses e de audiência assinalável na sociedade e na cultura portuguesa (HESPANHA, 2003):

a) para o século XIX, as Histórias de Portugal da autoria dos liberais monárquicos Luís Augusto Rebelo da Silva e Manuel Pinheiro Chagas (professores do Curso Superior de Letras de Lisboa), e do crítico do liberalismo monárquico Oliveira Martins;

b) para o século XX, as Histórias de Portugal da autoria do católico Fortunato de Almeida (professor do Liceu e da Escola Normal Superior de Coimbra), do republicano moderado Damiāo Peres (professor da Faculdade de Letras de Coimbra) e sua equipe de redatores ideo- 
logicamente diversa (professores de várias universidades e de vários institutos superiores), do monárquico antiliberal João Ameal e do democrata socialista António Sérgio.

São algumas lógicas das versôes intelectuais sobre o significado da função histórica desempenhada por António Vieira, radicadas nas diversas visôes do mundo dos vários autores escolhidos, que se pretende interpretar, pela primeira vez, na historiografia, não havendo portanto lugar a um estado da arte. Revelam a vontade de, através de historiografias com forte conteúdo de pedagogia cívica, contribuir para a construção de representaçôes identitárias portuguesas. Na manifestação profunda da sua vida e pensamento, para além das justificaçôes identitárias essencialistas na cultura portuguesa já descontruídas (LOURENÇO, 1978; MATTOSO, 1998; CATROGA, 2007; GODINHO, 2009, p. 49-122; ALMEIDA, 2017), é pertinente a observação crítica do ensaísta filosófico-literário Eduardo Lourenço: "António Vieira é uma mistura incomparável de sonhador por conta de um Reino futuro idealmente cristão e um não menos agudo observador da realidade" (LOURENÇO, 2008).

Tendo em vista a contextualização das representações parcelares sobre António Vieira que constam das Histórias de Portugal em análise interessa selecionar alguns elementos específicos da sua história de vida. Nasceu em Lisboa a 6 de fevereiro de 1608 e morreu em São Salvador da Bahia a 18 de julho de 1697. De origem mestiça, foi membro da Companhia de Jesus, pregador de sermôes, missionário, formador de opinião pública, político ao serviço de d. João IV e grande cultor da língua portuguesa. Viveu entre Portugal e a América Portuguesa, com uma curta permanência em Roma. Fez os estudos iniciais no colégio dos Jesuítas na Bahia, para onde se deslocou com oito anos, acompanhando o pai que foi para essa cidade exercer funçóes administrativas. Entrou aos quinze anos na Companhia de Jesus. Em 1641 embarcou para Portugal, fazendo parte da delegação que deu notícia da adesão da América Portuguesa a d. João IV e à Monarquia Portuguesa restaurada em 1 de dezembro de 1640 face à Monarquia Hispânica. Destacado conselheiro de d. João IV, foram-lhe atribuídas várias missões diplomáticas importantes (Paris, 1646-1647; Haia, 1646-1648; Roma/Santa Sé, 1650), e promoveu junto do rei o fim da discriminação dos cristãos-novos, alguns deles relevantes detentores de capital financeiro.

As críticas que fez ao Tribunal do Santo Ofício e à organização da Companhia de Jesus em território português provocaram o seu regresso à América Portuguesa em 1653, aceitando dirigir as missōes jesuítas na região do Maranhão, local de plantaçôes de algodão e de tabaco. Acumulou vários conflitos com os colonos brancos em virtude da denúncia da brutalidade desenvolvida contra os negros e os índios. Em 1654 voltou a Lisboa e em 1655 estava novamente no Maranhão com um diploma régio favorável aos índios, o que provocou novamente a forte oposição de colonos, acabando por ser expulso para Lisboa em 1661. D. João IV falecera em 1656 e em Lisboa o ambiente político não lhe será favorável. Conspirou com os partidários de d. Pedro contra d. Afonso e o conde de Castelo Melhor impôs, com apoio de d. Afonso, o seu desterro para o Porto, seguindo depois para Coimbra, onde terá a 
perseguição da Inquisição devido principalmente às suas teorias milenaristas de um sonhado Quinto Império. Viveu em Roma entre 1669 e 1675, permaneceu depois cerca de cinco anos em Lisboa e regressou definitivamente à Bahia em 1681.

No mundo diversificado das Histórias de Portugal de meados do século XIX até meados do século XX - o tempo histórico escolhido para a presente análise histórica - é fácil surpreender discursos de eruditos, de divulgadores e de historiadores que fixaram e comunicaram memórias elaboradas da experiência histórica portuguesa sob diversas matrizes historiográficas (historicismo alemão, historicismo positivista e historicismo metódico franceses, ou ensaísmo histórico) e matrizes ideológicas (liberalismo, socialismo, republicanismo ou tradicionalismo). Dentro de uma conjuntura europeia de construçáo e depois de transformação dos nacionalismos e de reinvenção das tradições nacionais (HOBSBAWM; RANGER, 1983, p. 101-307; HOBSBAWM, 1990, p. 101-162; RÉMOND, 2003, p. 235-245, 344-357), esses autores transportaram para o presente vivido uma clara intencionalidade cívica e política.

Ao longo dos séculos XIX e XX portugueses, em sintonia com dinâmicas culturais e políticas europeias, desenvolveu-se a construção e a transformação dos nacionalismos. Numa primeira fase (1820-1851), dentro da instável Monarquia Liberal, a construção dos nacionalismos foi marcada pelo confronto entre o nacionalismo progressista liberal e o nacionalismo tradicionalista antiliberal; numa segunda fase (1851-1910), no interior da estável Monarquia Liberal, diversificou-se o campo dos nacionalismos com os nacionalismos liberais, tradicionalistas, republicanos e católicos; e, numa terceira fase (1910-1945), durante a I República, a Ditadura Militar e o primeiro "Estado Novo", reconstruiu-se e alargou-se o campo dos nacionalismos por meio dos nacionalismos republicanos, monárquicos, católicos, tradicionalistas, autoritários e fascistas (BONIFÁCIO, 1998; RAMOS, 1994; CRUZ, 1980; CUNHA, 2001; LEAL, 1999; PINTO, 2015; ROSAS, 2019).

\section{Histórias de Portugal: conjuntura de construção dos nacionalismos}

Luís Augusto Rebelo da Silva (1822-1871) tentou seguir o modelo historiográfico romântico e crítico do historiador Alexandre Herculano (CATROGA, 1996, p. 39-85; GODINHO, 2010, p. 7-96) - a sua História de Portugal de importante nível científico não tinha ultrapassado o reinado de d. Afonso III (1248-1279) -, com quem conviveu proximamente na Biblioteca do Palácio da Ajuda em Lisboa, optando por estudar o período histórico moderno (séculos XV-XVIII), que pretendeu interpretar na História de Portugal nos séculos XVII e XVIII (5 v., 1860-1871), cujo título engana o leitor. Rebelo da Silva ficou nessa obra pelos finais do século XVI, com incursóes nos primeiros anos do reinado de d. João IV (1640-1656), podendo considerar-se que se está perante uma análise da anterioridade histó- 
rica do seu objeto de estudo essencial e que a morte aos 50 anos impediu que se concretizasse (LEAL, 2012, p. 557-566).

Seguiu a perspectiva historiográfica de Alexandre Herculano, que, segundo o historiador Fernando Catroga, tinha combinado a "apreensão das intencionalidades [humanas]" com as "explicações dominantemente sociais e institucionais", tratando, por conseguinte, de "levar em conta a dimensão poliédrica e objetiva das condicionantes históricas" (CATROGA, 1996, p. 67). Desse modo, verifica-se a análise de estruturas e de forças econômicas, sociais, políticas, culturais e psicológicas, a avaliação dos estudos realizados e a utilização de novas fontes que a sua pesquisa nos arquivos revelara. Numa parte da obra denominada "Forças morais", dentro do capítulo sobre o "Estado das Ciências e das Letras", Rebelo da Silva registrou que António Vieira tinha feito a admiração da primeira metade do século XVII, "suspenso diante do púlpito, ou antes da tribuna, do alto da qual sua grande voz abrasava os auditórios. [...] falando do céu, nunca tirava os olhos da corte e da cidade. A aula política era para ele o verdadeiro templo, e a eloquência sagrada, único meio de publicidade da época, a sua arma invencível" (SILVA, 1871, p. 296 e 298-299).

A imagem que nos transmite registrava, por um lado, o esmerado cultor da língua portuguesa - destacando o Sermão pelo bom sucesso das armas portuguesas (Bahia, 1640), o Sermão de Santo António, mais conhecido por Sermão de Santo António aos peixes (São Luís de Maranhão, 1654) e o Sermáo do bom ladrão (Lisboa, 1655) - e, por outro lado, o talentoso sacerdote jesuíta com fortes aspiraçôes políticas, usando a oratória pública e a influência privada com enorme mestria e paixão, não conseguindo, segundo Rebelo da Silva, "resistir ao gosto da época, ao amor do paradoxo e à vaidade de ser tido por profeta” (p. 299).

O triunfo do plano educacional católico ortodoxo da Companhia de Jesus em Portugal - Ratio atque institutio studiorum societatis Iesu (Ratio studiorum) -, principalmente no Colégio de Santo Antão (Lisboa), no Colégio do Espírito Santo (Évora) e no Colégio das Artes (Coimbra) (MENDES, 1993, p. 406-413), representou, na visão de Rebelo da Silva, marcada pelo ambiente antijesuítico da época do liberalismo romântico (1825-1866), com antecedentes no absolutismo iluminista do Pombalismo (1750-1777) e manifestaçóes futuras no demoliberalismo da I República (1910-1926) (FRANCO, 2006-2007), uma "declinação quase total dos estudos e do gosto", impedindo por algum tempo a renovação da "república das letras" desde as bases até à cúpula, "secularizando a instrução, abrindo novos caminhos às ideias e à forma", único processo eficaz, no seu entender, de combater a "corrupção literária" (SILVA, 1871, p. 299).

O antijesuitismo exprimiu a crítica dirigida a um setor específico do clero regular católico (Companhia de Jesus, fundada sob a liderança de Inácio de Loyola), pela influência educacional, cultural, científica e política que teve, desde o século XVI, a nível internacional. Representou uma modalidade específica do anticlericalismo geral que promovia a denúncia da interferência do clero católico nas áreas educacional e política. Essa mentalidade ideoló- 
gica e cultural foi promovida principalmente por setores radicais do pensamento iluminista, liberal e republicano, defensores do regalismo e do galicanismo, e seduziu de forma relevante pensadores e políticos portugueses, contribuindo para o debate sobre a laicidade e a secularização em Portugal. Sebastião José de Carvalho e Melo (1699-1782), o marquês de Pombal, seria o mais relevante antijesuíta português, reproduzindo-se esse discurso crítico nos séculos XIX e XX, onde se destacaram Joaquim António de Aguiar (1792-1884), Antero de Quental (1842-1891), Miguel Bombarda (1851-1910) e Afonso Costa (1871-1937).

A História de Portugal desde os tempos mais remotos até a atualidade concebida segundo o plano de Ferdinand Denis e por uma sociedade de homens de letras (8 v., 1867-1874), foi continuada por Manuel Joaquim Pinheiro Chagas (1842-1895) e pretendia ser uma obra de grande divulgação histórica para a formação pedagógica do cidadão liberal. Representou a primeira tentativa de conjunto de uma História de Portugal, em edição monumental, e exprimiu, dentro do consenso político liberal regenerador, como afirmou o historiador Jorge Borges de Macedo, a "síntese otimista que se prolonga por dezenas de anos, aceita a continuidade garantida em sucessáo e independência, não propriamente no melhor dos mundos, mas com o melhor dos resultados públicos" (MACEDO, 1995, p. xxxiv).

A inscrição da atividade religiosa e política de António Vieira é quase totalmente devedora dos fatos narrados por d. Luís de Meneses, $3^{\circ}$ conde da Ericeira (1632-1690), na História de Portugal restaurado (2 v., 1679 e 1698), e pelo escritor brasileiro João Francisco Lisboa (1812-1863), na obra inacabada Vida do padre António Vieira (1864). Pinheiro Chagas selecionou os momentos principais da sua história de vida para comunicar os traços característicos. Um deles era a eloquência convincente e entusiástica dos Sermóes, quer na América Portuguesa, quer em Portugal, transformando o púlpito em tribuna, onde proferia verdadeiros discursos políticos: "Isto deu-lhe sobre a corte e a opiniáo pública a influência que hoje pode obter um grande jornalista ou um eminente orador parlamentar" (CHAGAS, 1901, p. 334). Junto de d. João IV aconselhou a guerra defensiva prolongada contra a Monarquia Hispânica, o que, para Pinheiro Chagas, exprimia uma observação sábia face aos escassos recursos militares portugueses.

Outra característica notável assinalada era o fino tato político e diplomático, o que permitiu que ganhasse prestígio no círculo de poder de d. João IV (desembargador supremo e amigo político mais íntimo, que o havia de abandonar ao exílio, segundo Rebelo da Silva) e influência junto de notabilidades da sociedade de corte, onde destacou o secretário de estado Pedro Vieira da Silva. Pinheiro Chagas chamou também a atenção para algumas propostas econômicas, sociais e políticas sugeridas por Vieira: reduzir o fisco sobre os capitais dos cristãos-novos para evitar a sua fuga; criar companhias de comércio, à semelhança das holandesas (a companhia ocidental para explorar o comércio do Brasil surgiu em 1649); acabar com a frágil navegação em caravelas, substituindo por navios de maior tonelagem; permitir 
a entrada de estrangeiros nos negócios, desde que fossem inimigos da Monarquia Hispânica; abolir a distinção entre cristãos-velhos e cristãos-novos; reformar a Inquisição.

Não deixou Pinheiro Chagas de registar algumas opinióes críticas sobre condutas políticas de António Vieira: a sugestão da compra de Pernambuco aos Holandeses, o que mostrava falta de previsão política e falta de sentimentos patrióticos (p. 386), ou a aceitação de missões (sem caráter oficial) para vigiar os embaixadores portugueses em Paris e em Haia. Valorizou, contudo, as missóes diplomáticas oficiais que fez a Paris, Haia, Santa Sé e Madri ou a estratégia comunicada a d. João IV, que esteve para ser realizada na regência de d. Luísa de Gusmão, em 1660, de transferência da Corte para a América Portuguesa face à ameaça sobre a independência portuguesa por parte da França e da Monarquia Hispânica, após o Tratado dos Pirenéus de 1659 (p. 410). Esta História de Portugal inseriu uma gravura de António Vieira, que, na explicação final das gravuras do volume, averbou a qualidade de ser uma extraordinária figura de homem, "que foi um dos mais notáveis ornamentos da Companhia de Jesus".

As Histórias de Portugal de Rebelo da Silva e de Pinheiro Chagas inseriram-se na perspectiva liberal de nacionalização da história nacional e no ambiente nacionalista anti-iberista desenvolvido nas décadas de 50-70 do século XIX de onde surgiu em 1861 a Associaçáo $1^{\circ}$ de Dezembro/Comissão Central $1^{\circ}$ de Dezembro (hoje, Sociedade Histórica da Independência Nacional), a que pertenceram, entre outros, Alexandre Herculano, Luís Augusto Rebelo da Silva, Manuel Pinheiro Chagas, José Estêvão, Anselmo Braamcamp, José da Silva Mendes Leal e Inocêncio Francisco da Silva (CATROGA, 1985; PEREIRA, 1995) .

Joaquim Pedro de Oliveira Martins (1845-1894) publicou a sua História de Portugal (1879), dentro do plano de construção de uma Biblioteca das Ciências Sociais, contribuindo para o conhecimento histórico da vida portuguesa inserida no espaço ibérico comum, daí a simultânea obra História da civilizaçâo ibérica (1879), mas salvaguardando a nossa especificidade nacional dentro de uma visão federal peninsular (CATROGA, 1996, p. 117-159). Refletiu o historiador Jorge Borges de Macedo: "A História de Portugal de Oliveira Martins não deixa [...] de salientar ao lado de fatores de decadência, uma autonomia orgânica e funcional de surpreendente profundidade. Para o compreender, é necessário aquele outro livro que a complementa e a diferencia, que é o Portugal contemporâneo [1881]" (MACEDO, 1995, p. xxix-xxx).

Entre os fatores de decomposição nacional, a partir de 1580 com a União Ibérica, Oliveira Martins inseriu os modelos de educação dos jesuítas, que, segundo ele, tinham estagnado o florescimento cultural da Renascença, através de uma doutrina (ensino e pregação) de submissão e de obediência sistemáticas. O rei d. João IV, "beato e mole", e o povo, "macilento e inerte", permitiram que "o Portugal restaurado de 1640 [fosse] como devia ser um bom filho da Companhia [de Jesus]: uma sombra apenas, fantasma sem fisionomia nem caráter, passivo, obediente, nulo, idiota e beato” (MARTINS, 1972, p. 390-392). 
A conspiração jesuíta universal configurava, na visão de Oliveira Martins, um dos mais importantes fatores para explicar a degenerescência mental portuguesa desde finais do século XVI:

Esse programa de universal esterilização foi uma realidade em Portugal. O padre Vieira, exaltando o seu rei, acusando o castelhano nesse panfleto profético-político chamado a História do futuro, exclama: Ah! se os reis e monarcas considerassem que as púrpuras que vestem lhas empresta Deus da sua guarda-roupa, para que representem o papel de reis enquanto ele for servido! (MARTINS, 1972, p. 393).

O sociólogo Hermínio Martins observou dessa forma a persistência do mito antijesuíta: "A jesuitofobia e a teoria da conspiração universal associada a ela personificam aqui o todo, pois os Jesuítas haviam-se tornado o foco de teorias conspiratórias desde o século XVIII, difundidas com o apoio de grandes governantes e gozando de uma circulação quase universal [...]" (MARTINS, 2018, p. 358).

A imagem de António Vieira estava condicionada por essa visão antijesuítica, mas tal não impediu que autonomizasse o seu perfil cultural e político. Segundo Oliveira Martins, Vieira tinha sido para d. João IV o que o jurista João das Regras fora para d. João I, isto é, o justificador messiânico do novo rei e da nova dinastia, nesse caso da dinastia de Bragança, e o seu conselheiro essencial, enumerando as qualidades principais:

[...] homem superior e forte que está à frente do Portugal de agora, o guia, o mestre, o fundador, multiforme na capacidade, omnímodo da ação, missionário e diplomata, financeiro e estadista, e por sobre isso filósofo, moralista e literato: nesse homem, que é o padre António Vieira, o jesuíta, apraz-nos ver, ao mesmo tempo, o espírito da Companhia nos meados do XVII século, e o génio da naçáo, formado no seio da Sociedade de Jesus, por ela educada, por ela restaurada a independência política (MARTINS, 1972, p. 397).

Rei fraco e conselheiro forte, essa foi uma interpretação política de Oliveira Martins: "[...] o padre Vieira tinha reinado em nome de d. Joáo IV [...]" (p. 420) e prolongara a sua influência até o momento em que os jesuítas perderam algum poder na sociedade de corte com d. Afonso VI e o conde de Castelo Melhor, entre 1662 e 1667. Crítico da Companhia de Jesus, Oliveira Martins, apesar de reconhecer a genialidade de Vieira, não deixava de afirmar que ele era "ao mesmo tempo um representante do espírito nacional, ficou o tipo de Portugal restaurado, do Portugal jesuíta”, e a "doença nacional do Sebastianismo reverdecia na alma do padre sob a forma nova de um sonhado império, profetizado desde Isaías a David até S. Frei Gil de Santarém” (p. 397).

O Sebastianismo é um tópico do pensamento messiânico português, que se enraizou nas tradiçôes bíblicas (cristã e judaica), na resistência do messianismo judaico e dos cristãos- 
-novos face às condiçôes adversas na Península Ibérica, no mito castelhano do Encoberto e nas trovas profético-messiânicas populares de Gonçalo Anes Bandarra, sapateiro de Trancoso. A sua reinvenção far-se-á em meados do século XVI, em torno da esperança redentora do jovem d. Sebastião, que acabou provavelmente por morrer na batalha de Alcácer-Quibir (Marrocos) em 1578. Com a sua morte, deu-se a crise dinástica e Portugal perdeu a independência política em 1580, fazendo parte até 1640 da Monarquia Hispânica dos Habsburgo. $\mathrm{O}$ regresso desejado de d. Sebastiáo, que nunca apareceu, prolongar-se-ia na luta mental e política pela restauraçáo da independência de Portugal, expressa no mito nacional do Sebastianismo (BESSELAAR, 1987; ZÚQUETE, 2012, p. 355-401), que se reatualizou entre os séculos XVII e XX em diversas propostas identitárias, de matriz messiânica, sendo exemplos relevantes as que foram formuladas por António Vieira, no século XVII (HERMANN, 1994, cap. IV e V), José Pereira de Sampaio (Bruno) e Fernando Pessoa, no século XX (CATROGA; CARVALHO, 1996, p. 254-256, 308-313; MEDEIROS, 2008, p. 775-781).

\section{Histórias de Portugal: conjuntura de transformação dos nacionalismos}

No século XX, Fortunato de Almeida Pereira de Andrade (1869-1933) foi o primeiro a escrever uma História de Portugal (6 v., 1922-1929) de grande divulgação, "onde a sequência dos factos históricos se separava das condiçôes institucionais" (MACEDO, 1995, p. xxxvii), vindo a ser brevemente suplantada pela História de Portugal, de características monumentais, dirigida por Damião Peres. Devedor da reação do nacionalismo espiritualista católico ao racionalismo liberal e republicano anticlerical, Fortunato de Almeida incluiu na sua hermenêutica a necessidade de fundamentação documental (crítica de fontes), recusando, por exemplo, na linha de Alexandre Herculano, dar positividade histórica a algumas tradiçôes míticas (o "milagre de Ourique" ou as "Cortes de Lamego" onde teria sido aclamado d. Afonso Henriques), que podiam funcionar ao nível do imaginário nacional mas não da historiografia. Contudo, não seguiu uma interpretação marcada pelas transformaçóes estruturais na periodização histórica, usando a tradicional divisão por reinados, no interior dos quais organizava uma narrativa em torno de tópicos essenciais.

A recepção historiográfica de António Vieira será feita quando tratou dos escravos, do exército e da atividade econômica, dentro do tema das instituições políticas e sociais entre 1580 e 1816, seguindo muito de perto, principalmente, as obras de d. Luís de Meneses, $3^{\circ}$ conde da Ericeira (História do Portugal restaurado, 1679 e 1698), de André de Barros (Vida do apóstolo padre António Vieira, 1746) e de João Francisco Lisboa (Vida do padre António Vieira, 1864), como também as coletâneas de cartas e os estudos históricos de João Lúcio de Azevedo sobre Vieira e sobre os jesuítas no Grão-Pará (História de António Vieira, 1918-1921; O padre António Vieira julgado em documentos franceses, 1925). 
A primeira alusão ao sacerdote jesuíta que surge na História de Portugal de Fortunato de Almeida era a justificação econômica da aceitação da escravatura negra, citando palavras de Vieira escritas numa carta ao marquês de Nisa, em 12 de agosto de 1648: "[...] sem negros não há Pernambuco, e sem Angola não há negros [...]” (ALMEIDA, 1927, p. 128). Complementando, em seguida, com a defesa que os missionários jesuítas fizeram, durante mais de dois séculos, da liberdade dos índios, que os donatários e seus colonos não respeitavam (p. 130).

Por diversas vezes Fortunato de Almeida referiu a campanha pública de António Vieira a favor da liberdade dos índios, inclusivamente junto de d. Joáo IV, que lhe teria prometido resolver a situação. A Câmara do Maranhão, de que fizera parte Vieira, determinou por lei que estavam livres bastantes índios, mas a sua sorte continuaria a mesma, vindo a ocorrência de uma série de tumultos a obrigar à saída do padre jesuíta em junho de 1654 para Lisboa. Vieira voltou para o Maranhão em 1655 e lá permaneceu até ser expulso por colonos rebeldes em 1661. Como se afirmava na obra, só no reinado de d. José, pela lei de 6 de junho de 1755, se declarou estarem livres os índios do Maranhão e, somente através da lei de 8 de maio de 1758, será estendida essa decisão aos índios de todo o Brasil (p. 141).

A posição de António Vieira face à escravatura dos negros africanos na América Portuguesa reveste-se de complexidade teológica, histórica, econômica e política, não sendo obviamente finalidade deste artigo a sua abordagem, para o que existem estudos críticos relevantes (ZERON, 2011; SCHWARCZ; STARLING, 2015, p. 81-108; VIEIRA, 2018). Deve-se situá-la no ambiente da teologia moral ibérica da Segunda Escolástica/Escola Peninsular de Direito Natural (Francisco Vitória, Francisco Suárez, Luís de Molina, Fernão Rebelo ou João Baptista Fragoso) que estabelecia um discurso jurídico legitimador ambíguo sobre direito das gentes e guerra justa, pena de morte e escravatura, consentimento de venda e presúria ou comércio legal e contrabando para um cativeiro legítimo "apenas se proveniente de guerra justa ou da venda de si mesmos por máxima extrema; mas não já apenas para os forçar à conversão" (HESPANHA; SANTOS, 1993, p. 409). Por outro lado, a sociedade da colônia portuguesa na América "naturalizava" essa violência que servia para a mão de obra nas plantaçóes de açúcar, algodáo, tabaco ou café e para a Companhia de Jesus representava uma fonte de financiamento para as suas missôes de aculturação.

Vieira tinha tolerado a escravatura dos negros dentro dessa cultura católica que estabelecia a prioridade à "salvação da alma" face à "libertação do corpo", visto que a verdadeira escravatura era ser "escravo do pecado". Revoltou-se, no entanto, várias vezes, nos seus Sermôes e noutras atitudes públicas ou oficiais, contra a violência brutal infligida aos escravos negros. Inserido nessa mentalidade teológica e antropológica, entendia a escravidão, por um lado, como resultado da "guerra justa" e do "pecado humano", face ao qual se justificava a evangelização cristã para civilizar os pagãos; e, por outro lado, como mal necessário para a organizaçáo da produçáo econômica. Para Vieira, a dominaçáo de brancos sobre negros decorria da "força" e não da "natureza", dentro de uma humanidade única a ser cristianizada 
permanentemente. Acabou por aceitar a escravatura não por "razão de consciência", mas sim por "razão de Estado", ligada aos interesses políticos e econômicos da colonização na América Portuguesa. No entanto, deve insistir-se que não há "escravidão boa ou má, portanto não há escravidão melhor ou pior. Sempre e em qualquer lugar ela gera o sadismo, a rotinização da violência e a perversão social" (SCHWARCZ; STARLING, 2015, p. 99). Só a partir de meados do século XVIII euro-americano é que o abolicionismo do escravismo moderno se desenvolveu dentro da nova mundividência iluminista e liberal.

Valorizou também Fortunato de Almeida o papel de António Vieira como conselheiro militar de d. João IV, denunciando práticas administrativas erradas no Exército e propondo táticas militares nos conflitos armados da Guerra da Restauração (1640-1668) contra a Monarquia Hispânica, sendo um defensor da presença de engenheiros jesuítas estrangeiros (como o padre holandês Joannes Cieremans, conhecido em Portugal como João Cosmander) para a construção de fortificaçóes militares, ajudando a colmatar a nossa deficiente engenharia militar. Por fim, destacou o interesse que Vieira tinha posto na formaçáo de companhias de comércio colonial.

A partir de finais da década de vinte do século XX, a referência historiográfica portuguesa será a História de Portugal: edição monumental comemorativa do $8^{\circ}$ centenário da fundaçáo da nacionalidade (7 v., 1928-1935; índices, 1937; suplemento, 1954), dirigida por Damião António Peres (1889-1976), estando marcada por um patriotismo cívico aberto ao mundo, onde colaboraram republicanos e monárquicos (TORGAL, 1996, p. 265-272). Entre os seus autores estavam vários profissionais do ensino superior e aglutinou alguns dos grandes especialistas de então, como por exemplo, António Baião, Damião Peres, David Lopes, Hernâni Cidade, Jaime Cortesão, João Lúcio de Azevedo, Joaquim de Carvalho, Manuel Paulo Merêa, José Maria de Queirós Veloso ou Virgílio Correia. Na opinião do historiador Jorge Borges de Macedo,

marcou uma mudança de época na cultura histórica portuguesa. A História de Portugal de Damiáo Peres, conhecida como História de Barcelos, dado que a editora aí se situava, tem a marca de uma história individual pela consciência de destino que era precisamente o tema que estava em causa. Damiāo Peres, ao propô-la, não ignorava a luta para encontrar uma consciência de origem e finalidade de Portugal que constituía a essência e a finalidade da problemática histórica dos anos trinta (MACEDO, 1995, p. xxxviii).

Obra de síntese histórica erudita, devedora do programa da "Escola Histórica Metódica" de Charles Langlois e Charles Seignobos (BOURDÉ; MARTIN, 1983, p. 137-170), visando à grande divulgação e profusamente ilustrada, abriu campo intelectual à renovação historiográfica portuguesa das décadas de 1940 a 1970, sob o signo do programa da "Escola Histórica dos Annales" de Marc Bloch, Lucien Febvre e Fernand Braudel (p. 171-199), iniciada com 
a reorientação epistemológica e metodológica apresentada no livro do historiador Vitorino Magalhães Godinho, A crise da história e as suas novas diretrizes (1947), culminou no Dicionário de História de Portugal (4 v., 1963-1971), dirigido pelo historiador Joel Serrão, e na História de Portugal (2 v., 1972-1973), do historiador A. H. de Oliveira Marques, elaborada esta com base num plano inicial de que participaram, além de Oliveira Marques, os historiadores Vitorino Magalhães Godinho e António José Saraiva (MENDES, 1996, p. 318-324).

$\mathrm{Na}$ História de Portugal, dirigida por Damião Peres, as referências a António Vieira apareceram no volume correspondente à época de 1640-1815, o que era compreensível, reproduzindo-se duas gravuras, uma em Arte de furtar (1652), publicada anonimamente, tendo sido atribuída a António Vieira mas contestada desde o século XVIII e cuja autoria é de Manuel da Costa (jesuíta contemporâneo de Vieira) (GOMES, 1965, p. 42-45); outra, na Vida do apóstolo padre António Vieira (1746), de André de Barros. As alusôes a Vieira foram escritas por vários autores, sendo estas as principais:

a Sermão de Santo António, de 1642, onde se aconselhavam os nobres e os eclesiásticos a pagarem os impostos votados nas Cortes desse ano e se fazia alusão às missóes diplomáticas oficiais de Vieira à Holanda, França, Itália e Espanha em 1646-1650 e à sua fidelidade à regente d. Luísa de Gusmáo, após o golpe de Estado de d. Afonso VI e do conde de Castelo Melhor (escritas por Ângelo Ribeiro);

b. Conselho a d. João IV em 1643 para a fundação da Companhia Geral do Comércio do Brasil, criada em 1649 (escritas por Damiáo Peres);

c. Estatuto de relevante orador, epistológrafo e escritor de viagens (escritas por Hernâni Cidade);

d. Contributo para o conhecimento da fauna, flora e etnografia do Brasil (escritas por Luís de Pina);

e. Missões religiosas no Brasil em 1653-1661, salientando a necessidade de mão de obra escrava e o proselitismo da Companhia de Jesus (escritas por Jaime Cortesáo).

Jaime Cortesão chamou a atenção para um grave erro político cometido por d. João IV ao estipular na provisão régia de 21 de outubro de 1652 a autorização dada a António Vieira, como Superior das Missóes da Companhia de Jesus, para fundar na região do Maranhão quantas igrejas e missōes que achasse convenientes, concluindo:

Esta provisão, ditada, queremos acreditar, pelo humano e piedoso desejo de suavizar a sorte dos indígenas, enfermava dum excesso profundamente impolítico: colocava nas mãos de Vieira poderes discricionários que lhe permitiam chamar à Ordem [Companhia de Jesus] uma soberania sobre os indígenas que, em boa verdade, nunca deveria arrancar-se às mãos da autoridade civil. Criava-se assim um Estado dentro do Estado. Essa era, aliás, uma das 
tendências fundamentais da Companhia, que procurava afirmar-se por toda a parte e que lograra, como é sabido, o máximo das condiçôes propícias no Paraguai (PERES, 1934, p. 703).

Dentro do ambiente do $8^{\circ}$ Centenário da Fundaçáo da Nacionalidade e do $3^{\circ}$ Centenário da Restauração da Independência em 1940 - Duplo Centenário (CATROGA, 1996, p. 578-601) -, João Ameal (1902-1982), de nome completo Joáo Francisco de Barbosa Azevedo de Sande Aires de Campos ( $3^{\circ}$ conde do Ameal), escreveu uma História de Portugal (1940), devedora de profunda pesquisa e reflexão históricas, mas inserida na matriz do nacionalismo organicista e historicista do "Estado Novo" salazarista (TORGAL, 1996, p. 244247). As qualidades comuns atribuídas a António Vieira estavam aqui também presentes: glória da Companhia de Jesus, extraordinário orador, paladino do Portugal restaurado, eminente diplomata ao serviço de d. João IV, negociador de várias políticas estaduais (AMEAL, 1940, p. 443-446). Atribuiu-lhe a defesa da ideia de transferência da Corte para o Brasil em caso de ameaça de ocupação estrangeira de Portugal, identificando momentos históricos em que essa ideia tinha ocorrido na vida nacional, sendo concretizada face à primeira invasão napoleônica: 1580, 1644, 1659, 1762, 1801, 1803 e 1807.

João Ameal destacou o caráter providencial de d. João IV, fundador da dinastia de Bragança, repetindo a ideia do seu mestre de pensamento, o intelectual nacionalista monárquico integralista António Sardinha (1887-1925), de ele ter sido o "segundo fundador da pátria portuguesa" (p. 458). Considerou também que tinham sido escribas a mando do conde-duque de Olivares ("primeiro-ministro" de Filipe IV, da Monarquia Hispânica) que criaram a "triste lenda" de d. João IV se deixar subjugar pelas influências de d. Luísa de Gusmão e de António Vieira (p. 455-456). Na análise das correntes de opinião dentro da sociedade de corte após 1640, João Ameal estabeleceu, o que noutras Histórias de Portugal já tinha aparecido, o choque entre dois grupos principais: o grupo de António Vieira, em que estavam o duque do Cadaval, o conde de Soure, o conde de Pombeiro e Pedro Vieira da Silva; e o grupo do conde de Castelo Melhor, com o conde de Atouguia e Sebastiáo César Menezes (p. 470).

Neste itinerário crítico através de Histórias de Portugal, refira-se por fim o intelectual democrata socialista António Sérgio de Sousa (1883-1969), opositor cultural e político do nacionalismo autoritário do "Estado Novo" salazarista, com a sua História de Portugal (1929, edição espanhola), que teria uma edição crítica definitiva na Breve interpretação da História de Portugal (1972), orientada por Castelo Branco Chaves, Vitorino Magalhães Godinho, Rui Grácio e Joel Serrão (PEREIRA, 1983; MENDES, 1996, p. 277-284). Essa obra será elaborada dentro de uma visão cosmopolita crítica dos nacionalismos tradicionalistas e formalizou um tipo de ensaísmo histórico-sociológico (CUNHA, 2012, p. 63-73), aplicando o que denominou de "método racionalista", em que valorizou os fatores econômicos e sociais sobre o destino de Portugal, não sendo, por opção de autor, uma obra de construção crítica da história, dentro das regras metodológicas e epistemológicas do ofício de historiador. 
António Sérgio colocou problemas (a relação entre a terra e o mar, ou entre os fatores internos e os fatores externos), usou categorias instrumentais (a política da fixação e a política do transporte), apontou visôes de conjunto (incorporação e organização da metrópole; expansão marítima e colonial; tentativas de remodelação metropolitana após o triunfo do liberalismo) e pretendeu encontrar um fio condutor que ordenasse a construção e a evolução nacional (o caráter universalista português), sem deixar, por vezes, de se condicionar por preconceitos (o mito da decadência portuguesa desde o século XVI ou o mito redentor dos estrangeirados portugueses desde o século XVIII).

António Vieira foi referido dentro da abordagem das questôes político-religiosas do século XVII, que, segundo António Sérgio, tinham sido uma das razões dos "germes da decadência" nacional, aí inserindo a Inquisição e a Companhia de Jesus, cuja introdução datava de 1540: "O que, dos Jesuítas, mais repugna à consciência de hoje é o ideal a que se propuseram, os seus princípios de ordem política, o que havia de cadavérico, de formalista, de exteriorista, em suma, na sua maneira de encarar as coisas, contrária, por natureza, a todo o progresso espiritual" (SÉRGIO, 1977, p. 99-100). Pouco depois de se estabelecerem em Portugal, afirmou António Sérgio, dominavam o ensino público, a Universidade de Évora, governavam nas famílias das classes altas, fiscalizavam a atividade intelectual ou desenvolviam forte proselitismo missionário.

António Sérgio referiu quatro jesuítas relevantes: S. Francisco Xavier, apóstolo das Índias, padres Anchieta, Nóbrega e Vieira na América Portuguesa - "o grande Padre António Vieira, [homem] político ativíssimo, orador [de imaginação] arquipujante, prosador dos maiores da nossa língua", atribuindo-lhe uma qualidade de sábia antecipação: "As minas [de ouro e de diamantes] desorganizaram a economia do Brasil, como previra António Vieira. Grande parte dos moradores acorreram a procurá-las, levando os seus escravos, que tinham ocupados nas lavouras. Os mantimentos faltaram, a vida encareceu” (p. 100 e 118).

\section{Considerações finais}

O mundo das relaçôes entre história, ideologia e cidadania é um campo complexo. A ideologia serve para a história como um dos contributos para pôr problemas e colocar hipóteses na organização do questionário historiográfico; a história serve à cidadania, dotando-a de ferramentas de explicação e conservação do passado para intervir no presente com o fito no futuro (GODINHO, 2011, p. 123-174). Todos os autores das sete Histórias de Portugal têm uma envolvência política no espaço público, utilizando a história como legitimadora do presente e dispunham de uma perspectiva da história como formadora da cidadania, alguns deles com pertença a partidos políticos ou grupos cívicos em determinados momentos da sua vida cívica. 
Encontra-se nessas Histórias de Portugal a seleção de características comuns sobre António Vieira para identificar exemplaridades de "herói" nacional - escritor exímio da língua portuguesa, orador brilhante, missionário devotado, conselheiro político e militar do rei ou diplomata ao serviço do Estado -, havendo referências em quatro (Rebelo da Silva, Oliveira Martins, Damião Peres por intermédio de Jaime Cortesão, e António Sérgio) ao seu proselitismo jesuíta com interferência na esfera política para o condenar, o que se compreende dada as posiçóes anticongreganistas desses autores (particularmente críticos da Companhia de Jesus), numa (Fortunato de Almeida) a recordação da aceitação da escravatura dos negros e da defesa da liberdade dos índios, e noutra (Damiáo Peres por intermédio de Ângelo Ribeiro) releva-se o aconselhamento feito no Sermão de Santo António (1642) aos nobres e eclesiásticos para pagarem os impostos votados nas Cortes.

Nesse conjunto de traços característicos fragmenta-se naturalmente a unidade profunda da obra literária, do apostolado missionário e da ação política de António Vieira, inserida na lógica barroca de unidade tomista no século XVII católico europeu. Contudo, não se deve esquecer o lugar específico onde estão inscritas e a função pública que as histórias nacionais adquiriram - impregnadas ainda de elementos fortes da visão de magistra vitae através dos exempla - antes da mudança de paradigma historiográfico provocada principalmente pela historiografia francesa, reunida na revista Annales d'histoire économique et sociale, fundada por Lucien Febvre e Marc Bloch em 1929, que aprofundará também em Portugal a profissionalização do ofício de historiador, a construçáo científica da historiografia e a modernização da pedagogia e do ensino da História.

\section{Fontes}

ALMEIDA, Fortunato de. História de Portugal. V. V. Coimbra: Edição do Autor, 1927. AMEAL, João. História de Portugal. Porto: Livraria Tavares Martins, 1940.

CHAGAS, Manuel Pinheiro. História de Portugal, popular e ilustrada. 3. ed. V. 5. Lisboa: Empresa da História de Portugal, [s.d. 1871?] 1901.

MARTINS, Oliveira. História de Portugal. 16. ed. Lisboa: Guimarães Editores, [1879] 1972.

PERES, Damiāo (org.). História de Portugal, V. VI. Barcelos: Portucalense Editora, 1934.

SÉRGIO, António. Breve interpretação da história de Portugal. 7. ed. Lisboa: Sá da Costa Editora, [manuscrito, s.d.] 1977.

SILVA, Luís Augusto Rebelo da. História de Portugal nos séculos XVII e XVIII. V. V. Lisboa: Imprensa Nacional, 1871.

VIEIRA, Padre António. Cada um é da cor do seu coração: negros, ameríndios e a questão da escravatura em Vieira. Organização e introdução de José Eduardo Franco, Pedro Calafate 
e Ricardo Ventura; prefácio de Viriato Soromenho-Marques. Lisboa: Temas e Debates/ Círculo de Leitores, 2018.

\section{Referências}

ALMEIDA, Onésimo Teotónio. A obsessão da portugalidade: identidade, língua, saudade \& valores. Lisboa: Quetzal Editores, 2017.

ARIÈS, Philippe. Le temps de l'histoire. Paris: Éditions du Seuil, 1986.

BESSELAAR, José van den. O Sebastianismo: história sumária. Lisboa: Ministério da Educação e Cultura/Instituto de Cultura e Língua Portuguesa, 1987.

BONIFÁCIO, Maria de Fátima. Liberalismo e nacionalismo na primeira metade do séc. XIX. História, Lisboa, n. 3, p. 30-35, 1998.

BOURDÉ, Guy; MARTIN, Hervé. Les écoles historiques. Paris: Éditions du Seuil, 1983.

CALAFATE, Pedro. A mundividência de António Vieira. In: CALAFATE, Pedro (org.). História do pensamento filosófico português. V. II. Lisboa: Editorial Caminho, 2001. p. 703-731. CASTRO, Aníbal Pinto de. O essencial sobre o padre António Vieira. Lisboa: Imprensa Nacional-Casa da Moeda, 2008.

CATROGA, Fernando. Antero de Quental: história, socialismo, política. Lisboa: Editorial Notícias, 2001.

CATROGA, Fernando. Nacionalismo e ecumenismo: a questão ibérica na segunda metade do século XIX. Cultura - história e filosofia, Lisboa, v. IV, p. 419-463, 1985.

CATROGA, Fernando. Alexandre Herculano e o historicismo romântico. In: TORGAL, Luís Reis; MENDES, José Maria Amado; CATROGA, Fernando (autores). História da história em Portugal (sécs. XIX-XX). Lisboa: Círculo de Leitores, 1996. p. 39-85.

CATROGA, Fernando. História e ciências sociais em Oliveira Martins. In: TORGAL, Luís Reis; MENDES, José Maria Amado; CATROGA, Fernando (autores). História da história em Portugal (sécs. XIX-XX). Lisboa: Círculo de Leitores, 1996. p. 117-159.

CATROGA, Fernando. O duplo centenário (1940). In: TORGAL, Luís Reis; MENDES, José Maria Amado; CATROGA, Fernando (autores). História da história em Portugal (sécs. XIX-XX). Lisboa: Círculo de Leitores, 1996. p. 579-601.

CATROGA, Fernando. Os passos do homem como restolho do tempo: memória e fim do fim da história. 2. ed. Coimbra: Almedina, 2011.

CATROGA, Fernando. Portugal como "corpo" e como "alma" (sécs. XIX-XX). Revista de História das Ideias, Coimbra, v. 28, p. 245-75, 2007.

CATROGA, Fernando; CARVALHO, Paulo A. M. Archer de. Sociedade e Cultura Portuguesas II. Lisboa: Universidade Aberta, 1996. 
CRUZ, Manuel Braga da. As origens da democracia cristã e o salazarismo. Lisboa: Editorial Presença/Gabinete de Investigações Sociais, 1980.

CUNHA, Norberto. O tradicionalismo integralista. In: Poiética do mundo: homenagem a Joaquim Cerqueira Gonçalves. Lisboa: Ediçôes Colibri/Departamento de Filosofia e Centro de Filosofia da Universidade de Lisboa, 2001. p. 375-399.

CUNHA, Norberto. Ensaísmo, crítica e problemática da história. In: MATOS, Sérgio C.; JOÃO, Maria Isabel (orgs.). Historiografias e memórias (sécs. XIX-XX). Lisboa: Centro de História da Universidade de Lisboa/Centro de Estudos das Migraçôes e das Relaçôes Interculturais da Universidade Aberta, 2012. p. 63-73.

FEBVRE, Lucien. Combates pela história. V. I. Lisboa: Editorial Presença, 1977.

FINLEY, Moses I. Uso e abuso da história. São Paulo: Martins Fontes, 1989.

FOUCAULT, Michel. A ordem do discurso. Lisboa: Relógio d'Água Editores, 1977.

FOUCAULT, Michel. O que é um autor? 3. ed. Lisboa: Vega, 1992.

FRANCO, José Eduardo. O mito dos jesuitas em Portugal, no Brasil e no Oriente (sécs. XVI a XX). V. 1 e 2. Lisboa: Gradiva Publicaçôes, 2006-2007.

GODINHO. Vitorino Magalhães. A crise da história e as suas novas diretrizes. 3. ed. Lisboa: Imprensa Nacional-Casa da Moeda, 2013.

GODINHO, Vitorino Magalhães; DIAS, Eurico Gomes (orgs.). Alexandre Herculano: o cidadão e o historiador. Antologia. Lisboa: Imprensa Nacional-Casa da Moeda, 2010.

GODINHO, Vitorino Magalhães. Ensaios e estudos. V. I. Lisboa: Sá da Costa Editora, 2009. GODINHO, Vitorino Magalhães. Problematizar a sociedade: iniciaçáo à sociologia itinerário de reflexão. Lisboa: Quetzal Editores, 2011.

GOMES, J. Pereira. Manuel da Costa autor da "Arte de Furtar". Colóquio, Lisboa, n. 34, p. 42-45, 1965.

HERMANN, Jacqueline. No reino do Desejado: a construção do sebastianismo em Portugal, séculos XVI e XVII. São Paulo: Companhia das Letras, 1998.

HESPANHA, António Manuel. A História na cultura portuguesa contemporânea.doc. Academia.edu, 25 dez. 2003. Disponível em:

https://www.academia.edu/1480319/Hist\%C3\%B3ria_da_cultura_portuguesa_ contempor\%C3\%A2nea. Acesso em: 5 out. 2019.

HESPANHA, António Manuel. Categorias: uma reflexão sobre a prática de classificar. Análise Social, Lisboa, n. 168, p. 823-840, 2003.

HESPANHA, António Manuel; SANTOS, Maria Catarina. Os poderes num império oceânico. In: MATTOSO, José (org.). História de Portugal. V. 4. Lisboa: Círculo de Leitores, 1993. p. 409. 
HOBSBAWM, E. J. Nations and nationalism since 1780: programme, myth, reality. Cambridge: Cambridge University Press, 1990.

HOBSBAWM, Eric; RANGER, Terence (orgs.). The invention of tradition. Cambridge: Cambridge University Press, 1983.

LEAL, Ernesto Castro. História e cidadania: Luís Augusto Rebelo da Silva no liberalismo português. In: GARRIDO, Álvaro; COSTA, Leonor Freire; DUARTE, Luís Miguel (orgs.). Estudos em homenagem a Joaquim Romero Magalhäes: economia, instituições e império. Coimbra: Ediçốes Almedina, 2012. p. 557-566.

LEAL, Ernesto Castro. Nação e nacionalismos: a Cruzada Nacional D. Nuno Álvares Pereira e as origens do Estado Novo (1918-1938). Lisboa: Ediçốes Cosmos, 1999.

LOURENÇO, Eduardo. Revisitaçáo da mitologia anteriana. In: QUENTAL, Antero de. Causas da decadência dos povos peninsulares nos últimos três séculos. Lisboa: Ediçóes Tinta-daChina, 2008. p. 9-29.

LOURENÇO, Eduardo. O labirinto da saudade: psicanálise mítica do destino português. Lisboa: Publicaçóes Dom Quixote, 1978.

LOURENÇO, Eduardo. Padre António Vieira: do império do verbo ao verbo como império. Texto lido na sessão de homenagem ao Padre António Vieira. Academia das Ciências de Lisboa, 6 fev. 2008. Disponível em: www.snpcultura.org/id_padre_antonio_vieira_imperio_ verbo.html. Acesso em: 9 out. 2019.

MACEDO, Jorge Borges de. Da história ao documento, do documento à história. Lisboa: Arquivos Nacionais/Torre do Tombo, 1995.

MACEDO, Jorge Borges de. Oliveira Martins e o liberalismo constitucional. Futuro Presente, Lisboa, n. 8, p. 9-12, 1981.

MARTINS, Hermínio. Reflexôes sobre as mudanças de regime em Portugal no século XX: um estudo transcronológico e transnacional. Lisboa: Imprensa de Ciências Sociais, 2018.

MATTOSO, José. A escrita da história: teoria e métodos. Lisboa: Editorial Estampa, 1988. MATTOSO, José. A identidade nacional. Lisboa: Fundação Mário Soares/Gradiva Publicaçóes, 1998.

MEDEIROS, Luísa. Sebastianismo. In: MARTINS, Fernando Cabral (org.). Dicionário de Fernando Pessoa e do modernismo português. Lisboa: Editorial Caminho, 2008. p. 775-781. MENDES, António Rosa. A vida cultural. In: MATTOSO, José (org.). História de Portugal, v. 3. Lisboa: Círculo de Leitores, 1993. p. 375-421.

MENDES, J. Amado. Para uma nova visáo da história de Portugal: o Dicionário de Joel Serrão e a História de Portugal de Oliveira Marques. In: TORGAL, Luís Reis; MENDES, José Maria Amado; CATROGA, Fernando (autores). História da história em Portugal (sécs. XIX-XX). Lisboa: Círculo de Leitores, 1996. p. 318-324. 
NORA, Pierre. Mémoire collective. In: LE GOFF, Jacques; CHARTIER, Roger; REVEL, Jacques (orgs.). La nouvelle histoire. Paris: Retz-Cepl, 1978. p. 398-401.

PÉCORA, Alcir. Teatro do sacramento: a unidade teológico-retórico-política dos sermôes de Antônio Vieira. São Paulo: Edusp, 1984.

PEREIRA, Maria da Conceição Meireles. A questão ibérica: imprensa e opiniāo (18501870). V. 1 e 2. Porto: Faculdade de Letras da Universidade do Porto, 1995. Disponível em: https://repositorio-aberto.up.pt/handle/10216/55312. Acesso em: 8 set. 2019.

PEREIRA, Miguel Baptista. O neo-iluminismo filosófico de António Sérgio. Revista de História das Ideias, Coimbra, v. 5, n. 1, p. 21-88, 1983.

PINTO, António Costa. Os camisas azuis e Salazar: Roláo Preto e o fascismo em Portugal. Lisboa: Edições 70, 2015.

RAMOS, Rui. A segunda fundação (1890-1926). In: MATTOSO, José (org.). História de Portugal. V. 6. Lisboa: Círculo de Leitores, 1994.

RÉMOND, René. Introdução à história do nosso tempo: do antigo regime aos nossos dias. 2. ed. Lisboa: Gradiva Publicaçôes, 2003.

ROSAS, Fernando. Salazar e os fascismos: ensaio breve de história comparada. Lisboa: Edições Tinta-da-china, 2019.

SCHWARCZ, Lilia Moritz; STARLING, Heloisa Murgel. Brasil: uma biografia. Lisboa: Temas e Debates/Círculo de Leitores, 2015.

TORGAL, Luís Reis. Historiografia integralista e historiografia de regime. In: TORGAL, Luís Reis; MENDES, José Maria Amado; CATROGA, Fernando (autores). História da história em Portugal (sécs. XIX-XX). Lisboa: Círculo de Leitores, 1996. p. 244-247.

TORGAL, Luís Reis. Um símbolo da historiografia portuguesa: a História de Portugal de Barcelos. In: TORGAL, Luís Reis; MENDES, José Maria Amado; CATROGA, Fernando (autores). História da história em Portugal (sécs. XIX-XX). Lisboa: Círculo de Leitores, 1996. p. 265-272.

VALENTE, Vasco Pulido. A sociedade, o Estado e a história na obra de António Vieira: para a história da filosofia política em Portugal no século XVII. In: VALENTE, Vasco Pulido. Estudos sobre a crise nacional. Lisboa: Imprensa Nacional-Casa da Moeda, 1980. p. 95-240. VEYNE, Paul. Como se escreve a história. Lisboa: Edições 70, 1983.

ZERON, Carlos Alberto de Moura Ribeiro. Linha de Fé: a Companhia de Jesus e a escravidão no processo de formação da sociedade colonial (Brasil, séculos XVI e XVII). São Paulo: Edusp, 2011.

ZÚQUETE, José Pedro. O chefe imaginário. In: LEAL, Ernesto Castro; ZÚQUETE, José Pedro (orgs.). Grandes chefes da história de Portugal. Alfragide (Lisboa): Texto Editores, 2012. p. $355-401$. 